\title{
Elites in Switzerland
}

\section{The rise and fall of a model of elite coordination}

\author{
Felix Bühlmann, Marion Beetschen, Thomas David, \\ Stéphanie Ginalski and André Mach
}

Introduction: the new unpredictability of Swiss elites?

The modern Swiss state was founded in 1848, after a short civil war between the conservative-catholic cantons (states) and the liberal-protestant cantons. Even though the prevailing protestant elites dominated Swiss politics and the federal administration way into the twentieth century, certain observers attribute the success of the Swiss federal state, among other things, to the happy collaboration of elites from different religions, linguistic regions, cultures and social sectors (Katzenstein, 1985). According to this view, key for the functioning of Swiss elites were the traditions of civic participation, the militia army and the lacking professionalisation of parliament: first, voluntary social and civic participation in formal association has a strong tradition in Switzerland (Jost, 1991). These clubs, societies and parties produced the members of the Swiss elite and also served as their meeting places. Second, the Swiss army has to date only been marginally professionalised and relies on the militia principle: all Swiss men are obliged to join the army and some of them are promoted to higher ranks. Officers of the army are formed and meet during long training missions (Jann, 2003). Third, until as recently as the 1990s members of Swiss parliament did only get a rather rudimentary remuneration and professional politicians and members of parliament were rare. Entrepreneurs, professors, administrators or members of liberal professions met in parliament and were able to discuss political issues across social spheres. In combination with a particularly 
active role of economic interest groups and based on the territorial smallness of the country - one or two hours of train generally suffice to meet each other - these factors contributed to an emergence of a strong interrelation between political, economic and administrative elites. Swiss elites from different social fields know each other thanks to countless networks and easily reachable meeting places. Important decisions are taken based on consensus among interest groups, political parties and the administration (Kriesi, 1980).

This depiction of Swiss elites - as a group with a close solidarity, with short ways of decision and with keen exchange of information - could maintain itself for a long time. However, in the last years, voices critical about this strong concentration of power made themselves heard within the Swiss society. Terms such as "felt" or "political class" are no longer only used by critical media or left-wing intellectuals. They belong in the meantime to the vocabulary of certain fractions of the elites themselves and their omnipresence in the public debate might be a sign that the elite constellation typical for the Switzerland of the twentieth century is eroding (Wittmann, 2002; Parma, 2007). Several commentators contend that in recent years it has become increasingly difficult to identify a clear-cut elite governing Switzerland (Daum et al., 2014). New rifts between formerly united and solidary elite fractions begin to emerge and gain visibility, especially in the economic domain - for example between industry and finance, between large and small firms or between internationally and domestically oriented sectors of the economy. These transformations, originating in the financialisation and internationalisation of the economy in the last quarter of the twentieth century, have not only affected the economic elites, but also the political elites. We can presume that globalisation has profoundly transformed the twentieth-century Swiss model of elite coordination as a whole (Schneickert, 2015).

In this article, we first discuss the elite concept and present the Swiss context. Following this short theoretical and contextual introduction, we present our data and methods. We then show how the Swiss model of elite coordination has been built up and discuss how and why this configuration, beginning in the economic sector, began to erode in the last thirty years and entered a phase of less clear and more instable elite coordination. Finally, we explore some avenues of how the Swiss elite could develop in the future.

\section{Elites in Switzerland}

We define elites as social groups who, as a result of their institutional position or their resources, are able to influence the course of the society or take decisions that are crucial for its development at the national level (Hartmann, 2007, p. 17). Most 
scholars agree that the leading positions in the economic, political and administrative spheres come closest to such positions of influence (Hjellbrekke et al., 2007; Ellersgaard e Larsen, 2013). Even though they are not devoid of power, the media sphere or the academic sphere have not the same influence on the development of contemporary societies (Hartmann, 2007). Schematically we can distinguish two approaches of elites: theories of power and of conflict presume that there is only one single elite, spanning across different social spheres (Mills, 1956). This power elite would stem from a privileged social background, share a common ideology and have a deep and far reaching influence on society. As opposed to this, functionalist scholars contend that in Western societies several competing functional elites would have emerged (Keller, 1963). These elites would be recruited on the basis of their merit and performance. They would hardly speak to each other and could not be identified through a common ideology or lifestyle. In addition, their reach of influence would be limited by the boundaries of their functional sphere (politics, business, academia etc.). Recent elite studies mostly defend that in none of the European countries of the late twentieth century one of these two variants has imposed itself in an ideal-typical form (Hartmann, 2007). Elements of both models are present in most countries. However, there seem to be certain gradual differences that can be identified by analysing the educational paths leading to elite positions and the porosity between different spheres of a society. Whereas certain European societies, such as France, Spain (but also to a certain degree the UK with Oxbridge and the us with the Ivy League) have specific elite universities where most of the future leaders are trained, others such as Germany have a more pluralistic educational system where different educational paths can lead to elite positions. In addition, in some of these societies the boundaries between political, economic and administrative spheres are rather open, in others they are hermetically closed. This porosity between spheres can be biographical (as moves between spheres during a career, such as in the French model of "pantouflage") or simultaneous (as multiple positions in different spheres at the same time, for example an entrepreneur who is simultaneously member of parliament). Whereas in the case of France or Switzerland such porosity is widespread, in the German of British model, for instance, it is hardly possible to change between administration, politics and the corporate world. How these elements blend in a given society, at a given time, remains an empirical question and depends on the specific context.

Switzerland is a small country in Western Europe with a current population of about 8 million people. Culturally it is divided - and at the same time held 
together - by a multitude of cross-cutting cleavages. The most visible of these is the division in four linguistic regions, speaking German (65.6\%), French (22.8\%), Italian $(8.4 \%)$ and Rumantsch $(0.6 \%)^{2}$. Each of these regions is culturally (and sometimes institutionally) influenced by the respective neighbour country, i. e. Germany, France and Italy. Permanent international mobility, but also daily work commuting is rather widespread between Germany and the German part of Switzerland, France and the French part and Italy and the Italian part. Internally, the languages are organised according to a territorial principle (with some exceptions, each region has only one language) and only few people speak all official languages. The elites, and especially the political and administrative elites in Bern, are among the important mediators between the linguistic regions and often speak at least two of the languages. The divide between protestant and catholic areas was the origin of the civil war leading to the foundation of the modern Swiss state in 1848 and kept dominating the political landscape well into the twentieth century. It was also reflected in the party system, as the liberal-democratic party family was mainly composed of the protestant winners of the civil war. This fraction was largely dominant in the federal administration, supplied most of university professors and was dominant in the federal government as well. Only in 1891 the catholic-conservative party received a seat in the seven-member Federal Council, in 1919 the second one. The social-democratic party, as representatives of the rising working class, the third force of the Swiss political system, gained in influence in the first half of the twentieth century. They had their first seat in government in 1943 and then became (after some turbulences) an important party of a consensual government-system, with a second seat from 1959 onwards. The last partner in this government system, with one seat from 1959 on, was the initially agrarian and small-owner oriented Swiss People's Party. Going through a major internal transformation towards a populist-nationalist party from the 1980s onwards (under the leadership of Christoph Blocher) this party became more recently the largest party and has now also a second member in the government (since 2003, to the detriment of the catholic-conservative party). Economically Switzerland was among the earliest industrialised countries in Europe and from early on was characterised by a divided economic structure (Hettling et al., 1998; Tanner, 2016): on the one hand, it featured early on many multinational firms, was very international, export-oriented and strongly financialised. Especially the pharmaceutical industry (Roche, Novartis), the machine industry (ABB, Sulzer, Schindler), the watchmak-

2. These values represent the situation in 2010 (Swiss Statistical Office). About $8.7 \%$ indicated a nonofficial language as their mother tongue. It was possible to indicate several languages as mother tongue. 
ing industry (Swatch), and the banking sector (UBS, Credit Suisse) belong to this fraction of the Swiss economy. On the other hand, there is a strongly protected domestic and national sector, including domains such as agriculture, construction, retail and brewing. The Swiss economy profited not only from its early industrialisation, but has also been (more or less) spared by the two World Wars and major political upheavals. In addition, from 1937 onwards it profited from a relative peace between the unions and the interest groups of the entrepreneurs. A final important element of Swiss capitalism are its corporatist features: Since the end of the nineteenth century, the Swiss economy is co-regulated by a neocorporatist system of economic interest groups, for certain sectors also by cartels, for others by strong links between firms (in the form of interlocking directorates).

\section{Data and method}

To understand the formation of elites in the Swiss context and the relationship between different elite fractions in Switzerland, we rely on a data base of more than 20 thousand entries on members of the political, economic, political and administrative elite. ${ }^{3}$ These persons have been selected because of the institutional positions they occupied in the years 1910, 1937, 1957, 1980, 2000 and 2010. These dates have been chosen partially for reasons of data availability and cover the twentieth century with a rhythm of more or less twenty years from 1910 onwards.

TABLE 1

Sample of the Swiss Elites

\begin{tabular}{l|cccccc}
\hline & 1910 & 1937 & 1957 & 1980 & 2000 & 2010 \\
\hline Business* & 264 & 290 & 312 & 325 & 323 & 351 \\
Politics** & 223 & 246 & 250 & 255 & 256 & 257 \\
AdMinistration & 76 & 95 & 103 & 119 & 108 & 117 \\
\hline Total & 563 & 631 & 665 & 699 & 687 & 725 \\
\hline
\end{tabular}

*When we concentrate on CEO's, the presidents of the boards and the so-called delegates of the board we get the following numbers: 1910 - 211; 1937 - 218; 1957 - 215; 1980 - 186; 2000 - 186; 2010 - 200.

${ }^{* *}$ In order to get the numbers of members of parliament, we have to deduce the seven members of the Swiss federal council (the ministers of the government).

3. See http://www.unil.ch/obelis. In a supplementary project, we currently study also academic elites in Switzerland. 
The data stem from a multitude of historical and contemporary sources. Besides the Swiss Historic Dictionary, we used different biographical lexicons, annual reports of firms, the website of the Swiss parliament and different libraries and archives.

In order to study the economic elites, we have collected data on the following persons: the president of the boards, the CEO's and the so-called board delegates of the 110 most important Swiss firms. Formally a one-tier model (as in the UK) the Swiss corporate governance system is composed of a non-executive board of directors ("Verwaltungsrat" in German and "Conseil d'administration" in French) headed by a president. This board nominates a "direction" headed by a CEO. In certain cases a delegate of the non-executive board is also member of the direction. The 110 most important firms have been chosen according to their number of employees, their turnover and their stock capitalisation. This includes companies in the industrial sector, in banking and insurances and in the service sector. In addition to these business leaders we have also included the members of the committees of the most important economic interest groups. As in other neocorporatist countries such as Germany or Austria, interest groups are an important part of the Swiss economic system. These interest groups both coordinate the Swiss corporate domain and defend their interests on a political level, by participating in the crucial consultation phase of the legislation processes and, if necessary, by strategically using the instrument of direct democracy (initiatives and referendums) (Mach, 2015). The committee members of the seven following interest groups are part of our sample: the Swiss Banking Association, Economiesuisse, the Swiss Employers' Association, the Swiss Trade Association, the Swiss Farmers' Union, the Swiss Federation of Trade Unions and the Christian National Trade Union Federation of Switzerland.

The sample of the political elites is composed of the persons occupying the following positions: a) the seven members of the Federal Council, the Swiss Government. From 1958 to 2003 the Federal Council was composed of two members of the Liberal Democratic Party, two members of the Christian Democratic Party, two members of the Social Democratic Party and one member of the Swiss People's Party; b) the 246 members of the two-chambered Swiss parliament (the Federal assembly), composed of the National Council (200 members, representative of the cantonal population) and the Council of States ( 46 members, each canton has two members, half-cantons have only one member);

The administrative elites are defined as the most influential civil servants in the federal administration. The federal administration is organized in seven departments and, as subdivisions of these departments, a series of federal offices. The persons occupying the following positions have been included in our sample: a) the Federal Chancellor (and the Vice-Chancellor) who are the direct intermediaries between 
the administration and the government and are sometimes called the "eight federal council". They are elected by the federal assembly and usually are members of a political party (which they represent in these positions according to a tacitly accepted rotation); b) the general secretaries and the adjuncts of the seven federal departments who directly serve the federal councils at the helm of the departments; c) the directors of all federal offices. In addition, we have also included: d) the directors of the Swiss National Bank (Switzerland's central bank) and e) all federal judges at the Federal Supreme Court in Lausanne. Finally we have information at our disposal on all members of extra-parliamentary commissions (EPC). EPCs are organisations which assume tasks on behalf of executive authorities, but which are essentially composed of persons who are not civil servants. These organisations are important intermediaries between the administration and other domains of the Swiss society (business, academia, civil society) and aim at expanding the expertise of the federal administration. They are particularly important for the preparliamentary phase of the legislative process.

For all the persons occupying these positions in the political, economic and administrative elite we have a large amount of biographical indicators which are organised in a database ${ }^{4}$. For this contribution we specifically employed information on the sex (men, women), the educational trajectory (without academic education, bachelor's and master's degree, PHD), the nationality (Swiss citizenship, European citizenship, other countries) and the military rank (those with an officer's rank vs. those without). In addition, we have created variables of membership in different organisations: corporate boards, extraparliamentary commissions (CPE), parliament and committees of interest groups.

Ascension and erosion of the Swiss model of elite coordination

\section{The sociodemographic fundament of Swiss elites}

Many Swiss believe that - in analogy to the system of direct democracy of which most Swiss citizens are quite proud - the access to the Swiss elite is particularly open, democratic and based on merit and performances. However, our empirical material shows that also Swiss society is characterised by steep hierarchies of class, gender and nationality (Levy et al., 1997). The ladders leading to elite positions in Switzerland are rather selective. They presuppose to be male, to stem from a well-off family, to have a university degree and to be in possession of a Swiss passport. Since the 1920,

4. A part of this data base is openly accessible at: www.unil.ch/eliteresearch. 
these criteria have become increasingly fundamental preconditions of the access to Swiss elites and are the secret of their social cohesion.

Swiss elite networks are based on male forms of sociability. Until the 1980, the access to elite positions was almost completely denied to women. Only since about thirty years we can observe a modest increase of the share of women in elite positions (see Table 2).

TABLE 2

The share of Women Among Swiss Elites (\%)

\begin{tabular}{l|cccccc}
\hline & 1910 & 1937 & 1957 & 1980 & 2000 & 2010 \\
\hline Business & 0.0 & 0.7 & 0.0 & 0.0 & 0.0 & 2.6 \\
Politics & 0.0 & 0.0 & 0.0 & 9.4 & 22.7 & 27.6 \\
AdMINISTRATION & 0.0 & 0.0 & 0.0 & 1.7 & 9.3 & 17.9 \\
Average & 0.0 & 0.2 & 0.0 & 3.7 & 10.7 & 16.0 \\
\hline
\end{tabular}

The increase of the share of women is best visible in the political sphere, to which, since the (very late) introduction of female rights to vote and to be elected in 1971, the access is regulated by popular vote. In the administrative and economic elites, where a small and homogenous group of men selects its future members without transparency and democratic control, the share of women is still very modest, with $18 \%$, respectively $3 \%$ in $2010^{5}$. We can therefore presume that links based on male forms of sociability have rather well functioned over a long period and only weakened in the last years.

Because of the fragile data situation (especially compared to other European countries), we know relatively little on the social origins of Swiss elites (Mach et al., 2016). In one of the few recent studies, based on data of the early 1990s, Rothböck et al. (1999) show that the fathers of political and economic elites enjoy clearly a higher social status than the fathers of the overall population. In addition, they profited also from a longer education, which seems to confirm that in Switzerland (as in other countries) an academic degree is an important threshold in order to become an elite member. Historically, following the trend within the overall population, ever more elite members possess an academic degree in Switzerland. However, the share of academically educated elite members varies according to the elite sphere (see Table 3 ).

5. When we include both the executive and the non-executive members of boards, these values are higher: $1.9 \%$ in $1980,7.1 \%$ in 2000 and $8.9 \%$ in 2010 (Ginalski, 2016). 
TABLE 3

Elite Members without a University Degree (\%)*

\begin{tabular}{l|cccccc}
\hline & 1910 & 1937 & 1957 & 1980 & 2000 & 2010 \\
\hline Business & 33.0 & 28.6 & 26.9 & 16.3 & 16.1 & 12.8 \\
Politics & 29.1 & 37.8 & 47.2 & 30.6 & 34.4 & 40.1 \\
Administration & 19.7 & 11.6 & 4.9 & 4.2 & 2.8 & 1.7 \\
Average & 29.7 & 29.6 & 31.1 & 19.5 & 20.8 & 20.7 \\
\hline
\end{tabular}

* Only elite members of whom we know that definitely possess no university degree are listed here. All the other persons either have a university degree or we lack data about their highest educational degree.

In particular among the top civil servant, the ratio of university degree holders is high. But also among the business elite their share rose to more than $85 \%$ in recent years, whereas the proportion of members of parliament without a degree from a university remains relatively high. This is partially a consequence of compositional shifts within the parties and the rise of the national-conservative Swiss People's Party (SPP $)^{6}$. While in $198045.2 \%$ of the social-democratic members of parliament are without a university degree, this share shrunk to $17.2 \%$ in 2000 . The trend among the parliament member of the populist SPP is inversed: in 1980 only $39.3 \%$ don't have an academic degree; in 2000 this share rose to 64.7\% (Pilotti et al., 2010; Pilotti, 2016).

From the 1920s onwards, Swiss citizenship became a further inclusion principle of the Swiss elites. While at the beginning of the twentieth century, the Swiss business elites (but also the academic elites for instance) were characterised by a large and important German fraction, immigration and business policies in the wake of the World War I led to an increasing "nationalization" of Swiss elites. As a consequence, "national citizenship" became an important mechanism of elite access that completed male sex and a higher education as the sociodemographic basis of Swiss elites. Based on this relatively homogenous sociodemographic fundament, the Swiss elites established in the interwar period a dense system of coordination, which became known in Switzerland under the name of "Filz" (felt) (Wittmann, 2002).

\section{The cohesion of Swiss elites}

In order to force through important decisions, elites not only rely on a common social background or shared educational curricula. They also tend to discuss, coordinate

6. In German it is "Schweizerische Volkspartei" (SVP), in French "Union démocratique du centre" (UDC). 
and share central concepts and strategies which are at the basis of their activities (Mills, 1956; Hartmann, 2007). Using their sociodemographical commonalities, the Swiss elite constructed during the interwar period a sophisticated system of coordination. They created a common style of thinking and shared tools through studies of law; they created institutional meeting places in order to regularly share information and opinions; and they produced a system where the multipositionality of the elites - personalities who were present in several elite spheres at the same time - occurred frequently.

Switzerland has no elite university system as France with the "grandes écoles" or, to a lesser degree, Great Britain with Oxford and Cambridge. The Swiss university system is decentralised as in Germany and elite recruitment is rather based on a combination of certain disciplines (law, engineering) and degrees (doctoral degrees are important, even though to a lesser degree than in Germany). The leading law faculties at the universities of Bern and Zurich formed and trained the Swiss elites of the twentieth century. At these faculties studied not only the top civil servants of the federal administration. Also future directors of banks and many members of parliament followed the very same curriculum in law. In 1957, for instance, 22.9\% of the top business leaders, $30.2 \%$ of parliament members and even $36 \%$ of top civil servants held a degree in law. Even though technical studies at the Federal Institute of Technology Zurich (ETHZ) had not the same generalist radiance as law, the education at this prestigious technical university facilitated the access to elite positions. In particular, the top managers of the machine industry, but also many administrative and political leaders studied at the ETHZ.

Institutionalised meeting places, where elite members could informally exchange about ideas or get to know each other are a second important aspect of elite coordination. "For men of my generation, the military general staff course was a business school” said for instance Philippe de Weck (1983, pp. 14-15), a former general director at UBS. He emphasises the creation of a common way of thinking and managing through the shaping training courses in the Swiss army.

Since the mid-1930s, the share of officers among elite members remains constantly high (Jann, 2003). With over $50 \%$, this share is highest among administrative elites, but also business elites (with in average $45 \%$ of officers) and political elites with values between $35 \%$ and $42 \%$ are particularly well represented among the ranked officers. As a comparison: only 2\% of all Swiss men have an officer's rank in 1980.

Thirdly, the Swiss political system, relying heavily on voluntary engagement, features a comparatively high number of persons who occupy positions in several fields simultaneously. In 1957, in the golden period of the traditional elite dispositive, for instance $43 \%$ of all members of parliament ( 105 out of 242 ) would sit in at least one, 
TABLE 4

Share of Elite Members with an Officer's Rank in the Swiss Army (\%)

\begin{tabular}{l|cccccc}
\hline & 1910 & 1937 & 1957 & 1980 & 2000 & 2010 \\
\hline Business elite & 30.3 & 44.1 & 43.6 & 46.8 & 35.6 & 21.9 \\
Political elite & 57.4 & 35.8 & 37.2 & 42.0 & 31.6 & 23.3 \\
Administrative ELIte & 53.9 & 54.7 & 56.3 & 52.1 & 50.9 & 34.2 \\
AVerage & 44.2 & 42.5 & 43.2 & 45.9 & 36.5 & 24.4 \\
\hline
\end{tabular}

often in several extra-parliamentary commissions; $19.5 \%$ ( 47 out of 242 ) would hold a mandate in the board of one of the 110 most important Swiss firms; and 20 out of $242(8.5 \%)$ would simultaneously be committee members of one of the seven top economic interest groups. Conversely, 24 out of 215 (11\%) top-managers occupied a political office in the federal parliament or in a cantonal government; $27 \%$ of the same managers were in the committee of an economic interest group and even 95 out of 215 , i.e. $44 \%$ of the business leaders sat in an extraparliamentary commission and so participated prominently in a crucial phase of the legislation process (which, in addition, is beyond democratic control).

The coordination within the business elites is equally important as the coordination between political, economic and administrative elites. Founded around the turn of the twentieth century, the economic interest groups became more closely integrated in the business policy making process (Eichenberger e Mach, 2011). The business leaders, frequently committee member of one of those interest groups, were now in close exchange with the federal administration and the political sphere. They were officially consulted concerning important economic policies within the legislation process and in their role as committee members they participated as key actors in the process of Swiss initiative and referendums politics.

In addition, through the participation in several boards, so-called "interlocking directorates" (or "interlocks"), emerged as new institutional linkages between Swiss firms. In these networks, the companies would exchange information, elaborate common strategies and resolve conflicts without the inference of the state (Ginalski et al., 2014). In the first half of the twentieth century, this network of interlocks became increasingly dense in Switzerland (see Figure 1).

The number of firms that were related trough the exchange of board members remained at a considerably high level until the 1980 s. $20 \%$ to $25 \%$ of board members of the most important Swiss firms would take part between 1937 and 1980 in at 
FIGURE 1

Network of Interlocking Directories of Board Members of the 110 Most Important Swiss Firms in $1957^{*}$

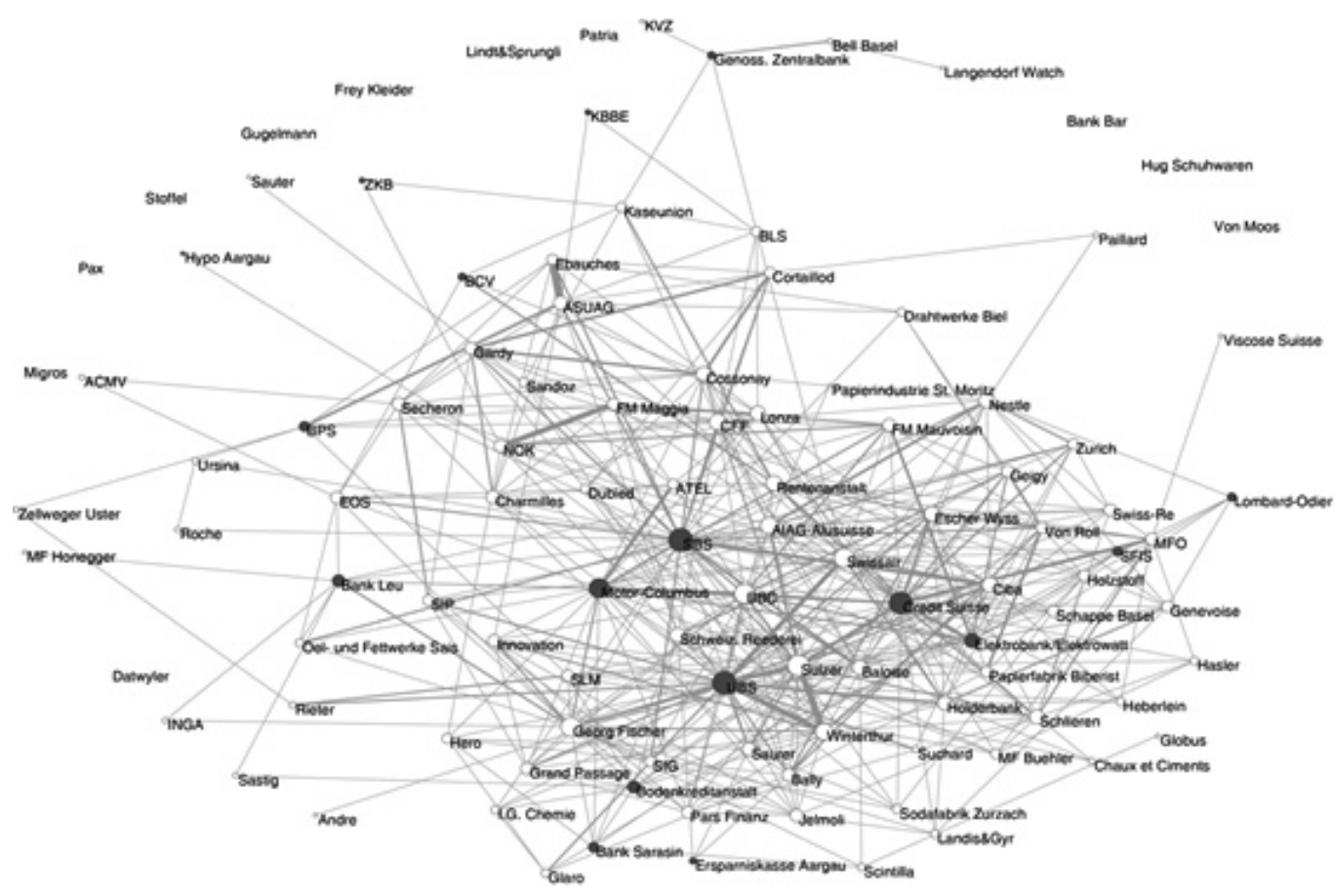

*The grey lines correspond to common board members; the bolder the lines are, the more board members the firms share with each other. Dark grey points: banks; white points: other firms. The size of the points corresponds to their centrality degree (number of links) in the network.

least two firms, between $7 \%$ and $10 \%$ were active in three or more boards. Certain prominent bankers, such as Fritz Richner (Swiss Bank Corporation ${ }^{7}$ ) or Robert Holzach (Swiss Bank Corporation) would hold in 1957 or 1980 up to ten board mandates simultaneously.

\section{Erosion of the networks as consequence of the economic evolution}

At the end of the 1980s, the first fissures appeared in the configuration of the Swiss elite, originating from the field of business. New management principals, the financialisation of the world economy and the process of Europeanisation led to a fundamental modification of the composition of the Swiss economic elites, which resulted in a loosening of the links between business, political and administrative elites.

7. This large bank merged with the Union Bank of Switzerland in 1998 and became the current UBS. 
FIGURE 2

Network of Interlocking Directories of Board Members of the 110 Most Important Swiss Firms in 2010*

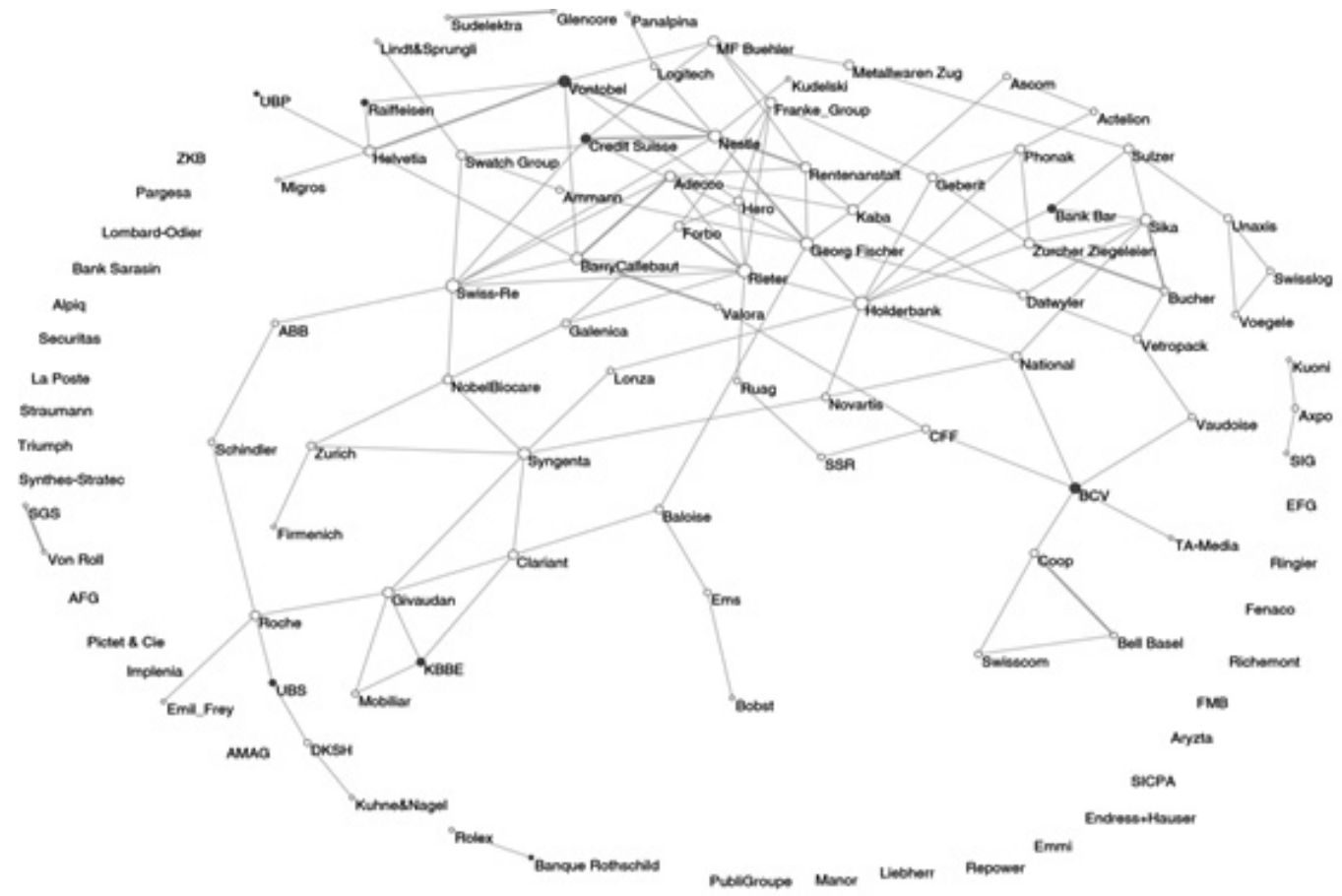

*The grey lines correspond to common board members; the bolder the lines are, the more board members the firms share with each other. Dark grey points: banks; white points: other firms. The size of the points corresponds to their centrality degree (number of links) in the network.

Fuelled by the shareholder value ideology and the opportunities of a liberalised financial market, the firms began to change their operating mode. Because industrial companies increasingly refrained from funding their activities by credits and increasingly relied on the financial markets, banks no longer needed a sophisticated system of monitoring. Consequently, the density of interlocking networks declined steeply since the 1990. In 2010, hardly any top managers still meet in the boards of firms. The network has vanished (see Figure 2). Almost a quarter of the 110 most important Swiss firms has no more links to another firm via a common board member; in 1980 only 6\% of all firms were isolated in the same way (David et al., 2015; Ginalski et al., 2014).

Secondly, the Swiss economy has, propelled by the process of European integration, become drastically more international between 1980 and 2010 (see Table 5). 
TABLE 5

Share of Foreign Top Managers in the 110 Most Important Swiss Firms *

\begin{tabular}{l|ccc}
\hline & 1980 & 2000 & 2010 \\
\hline EUROPEANS & $3.2 \%$ & $21.7 \%$ & $28.5 \%$ \\
Non-EUROPEANS & $0.5 \%$ & $1.1 \%$ & $6.0 \%$ \\
\hline TOTAL FOREIGNERS & $3.7 \%$ & $22.8 \%$ & $34.5 \%$ \\
TOTAL NUMBER & 186 & 186 & 200 \\
\hline
\end{tabular}

*Only CEO's and presidents of boards.

Until the year 2000 the managers of Swiss firms have been Europeanised; only after the turn of the century they have also become more global. In 2010, barely two thirds of the top managers of the 110 most important Swiss firms still have the Swiss citizenship ${ }^{8}$. The most dominant multinational corporations - Novartis, ABB, Nestlé, Credit Suisse and uBs - are all headed by global managers. Their educational and career profiles distinguish themselves clearly from those of the traditional Swiss business elites. Therefore, these international managers are often excluded - or even do not wish to enter - in the meeting places of the Swiss elites, which are shielded by nationality and co-optation.

Even wider than within the business elite, the gulf opens between the international business elites and the still very nationally oriented political and administrative elites. Not the least because the trenchantly nationalist politics of the now largest party, the Swiss People's Party, also begins to stain the parliamentary agenda.

TABLE 6

Multipositioning of Business Elites*

\begin{tabular}{l|ccc}
\hline & 1980 & 2000 & 2010 \\
\hline BOARD MEMBER IN PARLIAMENT & $10.8 \%$ & $7.6 \%$ & $3.4 \%$ \\
BOARD MEMBER IN COMMITTEE OF INTEREST GROUP & $3.9 \%$ & $2.5 \%$ & $3.1 \%$ \\
BOARD MEMBER IN EXTRAPARLIAMENTARY COMMISSION & $18.0 \%$ & $6.8 \%$ & $3.7 \%$ \\
\hline NUMBER OF TOTAL BOARD MEMBERS & 846 & 800 & 819 \\
\hline
\end{tabular}

*We took into account all members of the executive boards of the 110 most important firms.

8. When concentrating on the thirty largest firms listed in the Swiss market index (swIX), 64\% of all members of top management teams are of foreign nationality. Also, internationally this share is exceptionally high: while 23\% of top managers are foreign citizens in France and 26\% in Germany, only Great Britain (with 51\%) comes close to Switzerland (Bühlmann et al., forthcoming). 
Only 3.4\% (28) of all board members of the 110 most important firms sit in the national parliament in 2010, whereas they were almost $11 \%$ (91) some thirty years ago (see Table 6). Also the participation of business leaders in extraparliamentary commissions is steeply declining. Only mandates at the top of business interest groups are still rather coveted by top managers (Eichenberger e Ginalski, 2016).

However, the unbundling of elites cannot be explained by the growing part of foreign managers alone. In the course of the internationalisation, also the managers possessing a Swiss citizenship did in fact change their profile. Symbolically, "international or cosmopolitan capital" (in the forms of an international education, stays abroad or linguistic competences) became an important resource in order to accede to top position in the large Swiss firms (Bühlmann et al., 2013). As a consequence, also "Swiss managers" grew more international and were no longer regularly to be seen at the meeting places of the traditional Swiss elites. Also, the administrative and political elites have adapted themselves slightly: while for instance in 1957 or 1980 still over $60 \%$ of the Swiss top civil servants ranked as officers of the Swiss army, this number shrunk to $42 \%$ in 2010 . Moreover, studies of law lose their function as intellectual cement of the Swiss elites rapidly: whereas in 1980 still $44 \%$ of the administrative elites, respectively $25.9 \%$ of the business elites had a law degree, these shares are reduced to $31.5 \%$ in the administration and $15 \%$ in the economy in 2010.

\section{Conclusions: Which new elite fractions try to seize the power in Switzerland?}

The Swiss elite configuration, established during the interwar period, has strongly eroded in the 1990s and 2000s. The elites of the different spheres have been unbundled. The members of the federal parliament for example now concentrate much more frequently full-time on their political mandate. The directors of the large Swiss firms define themselves as professional managers and have little directly political ambitions. Cultivating contacts with other societal actors is no more among their priorities - at least when it comes to the Swiss level.

In Switzerland, the current phase is a phase of transition. The old elite regime has melted down, but is not yet replaced by a new one. Typically, in such a transition phase we witness struggles between incumbents and challengers, the situation becomes confusing (Daum et al., 2014). But who tries currently to seize the power in Switzerland's political and economic arenas? In the political field, the parliament as a whole has become more relevant in the last decades, political debates do not lack poignancy (Sciarini, 2014). At the same time, the supporters of the Swiss People's Party could impose themselves increasingly and have in this way contributed to the decline of the emblematic party of the "Swiss felt", the liberal-democratic party. 
In the economic field the dynamic is diametrically opposed to this: in the 2000s globalised managers have become more important at the very top of the firms, in particular in the multinational firms (we can mention Joe Jimenez of Novartis, Joe Hogan of ABB, Oswald Grübel of uBs or Tidjane Thiam of Credit Suisse). These managers impress by the internationality of their careers. Their link to Switzerland, however, is rather superficial. This means that the political and economic winners in the struggle for power in the last years in Switzerland could not be more different. It seems as if two non-communicating universes would develop. Here the nationalistic SPP, who is against all things foreign and academic; there the hyperglobalised and cosmopolitan top managers, educated at the worldwide best business schools.

It would be short-sighted, however, to exclude a possible coalition of the winners: on the one hand, within the SPP maturates a so-called "academic fraction", which has rather original ideas when it comes to internationality ${ }^{9}$ - ideas that do not at all correspond to the image of yodelling cow farmers the SPP usually champions. Several influential politicians of this academic fraction of the SPP are against the European integration, but do not disapprove of international exchanges as such. To the contrary, they are in favour of a rather radical further globalisation - provided the independence of Switzerland remains warranted and the influx of foreign workers will be radically limited. Instead of an integration into the European project they plead for a focused deepening of the relationship with China or the Us. Inversely, it is not excluded that the (international) top managers become more nationally grounded in the near future and begin again to seek a closer relationship to Swiss politics. The future elite research in Switzerland must keep an eye on these victorious fractions in politics and business and how they relate to each other. Why on earth should the new powerful fractions refrain from trying to stabilise and defend their influence through new coalitions and new forms of coordination?

9. Several of the leaders of the SPP are also influential entrepreneurs whose companies are often very internationalised. 


\section{Bibliographic References}

Bühlmann, Felix et al. (2013), "Cosmopolitan capital and the internationalization of the field of business elites: evidence from the Swiss case”. Cultural Sociology, 7 (2): 211-229. . (forthcoming), "European top management careers: a field-analytical approach". European Societies.

Daum, Matthias et al. (2014), Wer regiert die Schweiz? Ein Blick hinter die Kulissen der Macht. Baden, Hier und Jetzt.

DAvid, Thomas et al. (2015), De la "Forteresse des Alpes» à la valeur actionnariale: histoire de la gouvernance d'entreprise suisse (1880-2010). Zürich, Seismo.

Eichenberger, Pierre \& Ginalski Stéphanie. (2016), “'Si vis pacem, para bellum': the construction of business cooperation in the Swiss machinery industry". Socio-Economic Review.

Eichenberger, Pierre \& Mach, André. (2011), “Organised capital and coordinated market economy: Swiss business interest associations between socio-economic regulation and political influence". In: Trampusch, Christine \& Mach, André (orgs.). Switzerland in Europe. London, Routledge, pp. 63-81.

EllersgaArd, Christoph Houman et al. (2013), "A very economic elite: the case of the Danish top CEOs”. Sociology, 47 (6): 1051-1071.

GinALSKI, Stéphanie. (2016), "Les femmes à la tête des grandes entreprises suisses: une analyse historique des inégalités de genre". Social Change in Switzerland, 7. Retrieved from: http:// www.socialchangeswitzerland.ch/?p=1027. Access: 5 jul. 2017.

Ginalski, Stéphanie et al. (2014), "From national cohesion to transnationalization: the changing role of banks in the Swiss company network (1910-2010)". In: DAVID, Thomas \& WeSTERHUIS, Gerarda (orgs). The power of corporate networks: a comparative and historical perspective. London, Routledge, pp. 107-123.

Hartmann, Michael. (2007), Eliten und Macht in Europa: ein internationaler Vergleich. Frankfurt, Campus.

Hettling, Manfred et al. (1998), Eine kleine Geschichte der Schweiz. Frankfurt, Suhrkamp.

Hjellbrekke, Johs et al. (2007), “The Norwegian field of power anno 2000”. European Societies, 9 (2): 245-273.

Jann, Ben. (2003), “Old Boy Network: Militärdienst und ziviler Berufserfolg in der Schweiz”. Zeitschrift für Soziologie, 32 (2): 139-155.

Jost, Hans-Ulrich. (1991), Geselligkeit, Sozietäten und Vereine. Zurich, Chronos.

Katzenstein, Peter J. (1985), Small states in world markets: industrial policy in Europe. Ithaca, Cornell University Press.

KeLler, Suzanne. (1963), Beyond the ruling class: strategic elites in modern society. New York, Random House. 
KRIESI, Hanspeter. (1980), Entscheidungsstrukturen und Entscheidungsprozesse in der Schweizer Politik. Frankfurt, Campus.

LEvy, René et al. (1997), Tous égaux? de la stratification aux représentations. Zurich, Seismo.

MACH, André. (2015), Groupes d’intérêt et pouvoir politique. Lausanne, PPUR.

$\mathrm{MACH}$, André et al. (2016). Les élites économiques suisses au 20 $0^{\mathrm{ème}}$ siècle. Neuchâtel, Alphil.

Mills, Charles W. (1956), The power elite. Oxford, Oxford University Press.

PARMA, Viktor. (2007), Machtgier: wer die Schweiz wirklich regiert. Zürich, Nagel \& Kimche.

Pilottr, Andrea. (2016). Entre démocratisation et professionnalisation: le Parlement suisse et ses membres de 1910 à 2016. Zurich, Seismo.

Pilotti, Andrea et al. (2010), "Les parlementaires suisses entre démocratisation et professionnalisation, 1910-2000”. Swiss Political Science Review, 16 (2): 211-245.

Rотнвӧск, Sandra et al. (1999), "Die Rekrutierung der politischen, wirtschaftlichen und wissenschaftlichen Eliten in der Schweiz: eine explorative Studie”. Schweizerische Zeitschrift für Soziologie, 25 (3): 459-496.

SChneickert, Christian. (2015), Nationale Machtfelder und globalisierte Eliten. Konstanz, UVK Verlagsgesellschaft.

SCIArini, Pascal. (2014), "Eppure si muove: the changing nature of the Swiss consensus democracy”. Journal of European Public Policy, 21 (1): 116-132.

TANner, Jakob. (2016), Geschichte der Schweiz im 20. Jahrbundert. München, C. H. Beck.

Weck, Philipp de. (1983). Un banquier suisse parle: entretiens avec François Gross. Fribourg, Michel.

Wittmann, Walter. (2002), Der helvetische Filz: eine geschlossene Gesellschaft. Bern, Huber. 


\section{Abstract}

\section{Elites in Switzerland: the rise and fall of a model of elite coordination}

The aim of this article is to understand the recent transformations of Swiss elites. Based on a database of political, economic and administrative elites covering the whole twentieth century, we investigate the social background, education and coordination mechanisms of Swiss elites. We find that for a long time, they maintained their power through a combination of a socially narrow recruitment and a coordination model including the army as meeting place, a corporatist organisation of the economy and multipositionality between political and economic fields. As a result of the increasing internationalisation of managers of Swiss firms, this model of elite coordination has eroded since the 1990s and led to a (relatively) unpredictable transition phase. Keywords: Swiss elites; Political, economic and administrative elites; Multipositionality.

\section{Resumo}

As elites na Suiça: ascensão e declínio de um modelo de coordenação das elites

O objetivo do artigo é entender as transformações recentes das elites suiças com base em um banco de dados sobre elites políticas, econômicas e administrativas que abrange todo o século XX. A partir desse conjunto de informações investigamos a origem social, educação e mecanismos de concertação das elites suíças. Detectamos que, por um longo tempo, mantiveram seu poder através da combinação de um restrito recrutamento social e de um modelo de concertação/coordenação incluindo as forças armadas como um ponto de referência, uma organização corporativa da economia e a multiposicionalidade entre os campos político e econômico. Como resultado do aumento da internacionalização dos gerentes de empresas suíças, este modelo de concertação experimenta um processo de deterioração desde os anos 1990, levando a uma fase de transição (relativamente) imprevisível.

Palavras-chave: Elites suíças; Elites políticas, econômicas e administrativas; Multiposicionalidade.

Texto enviado em 1/2/2017 e aprovado em 29/5/2017. DOI: 10.11606/0103-2070. ts.2017.125960.

FELIX BÜHLMANN is assistant professor, University of Lausanne, Switzerland. MARION BEETSCHEN is research fellow, University of Lausanne, Switzerland. THOMAS DAVID is full professor, University of Lausanne, Switzerland. STÉPHANIE GINALSKI is senior lecturer, University of Lausanne, Switzerland. ANDRÉ MACH is associate professor, University of Lausanne, Switzerland. 